\title{
Kedudukan Akal dalam Islam
}

The Position of Reason in Islam

\author{
Muhammad Amin \\ Universitas Muhammadiyah Makassar
}

\begin{abstract}
Abstrak
Allah swt., menganugerahkan akal kepada seluruh manusia yang merupakan kelebihan manusia dibanding dengan makhluk-makhluk-Nya yang lain. Dengan menggunakan akalnya manusia dapat membuat hal-hal yang dapat mempermudah urusan mereka di dunia. Tetapi segala yang dimiliki manusia sudah tentu ada keterbatasan-keterbatasan sehingga ada batas-batas yang tidak boleh dilewati. Meskipun Islam sangat memperhatikan dan memuliakan akal, tetapi tidak menyerahkan segala sesuatu kepada akal, bahkan Islam membatasi ruang lingkup akal sesuai dengan kemampuannya, karena akal terbatas jangkauannya, tidak akan mungkin bisa menjangkau hakekat segala sesuatu. Maka Islam menundukkan akal terhadap Wahyu dan Sunnah Nabi saw., artinya di dalam segala hal wahyu dan sunnah harus di dahulukan.
\end{abstract}

Kata kunci: Kedudukan Akal, Islam 


\begin{abstract}
Allah swt., Conferring reason to all human beings who are superior human beings compared to His other creatures. By using the wisdom of man can make things that can ease their affairs in the world. But everything that man has is of course there are limitations so there are boundaries that should not be passed. Although Islam is very concerned and glorifies the intellect, it does not surrender everything to the intellect, even Islam limits the scope of reason according to its ability, because the reason is limited in its reach, it will not be possible to reach the essence of all things. So Islam subjects reason to the Revelation and the Sunnah of the Prophet, meaning in all things the revelation and the sunnah should be first.
\end{abstract}

Keywords: The position of Intellect, Islam

\section{PENDAHULUAN}

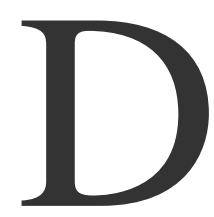

alam Islam, akal memiliki posisi yang sangat mulia. Meski demikian, bukan berarti

akal diberi kebebasan tanpa batas dalam memahami agama. Islam memiliki aturan untuk menempatkan akal sebagaimana mestinya. Bagaimanapun, akal yang sehat akan selalu cocok dengan syariat Allah swt, dalam permasalahan apa pun.

Akal adalah nikmat besar yang Allah swt titipkan dalam jasmani manusia. Akal merupakan salah satu kekayaan yang sangat berharga bagi diri manusia. Keberadaannya membuat manusia berbeda dengan makhluk-makhluk lain ciptaan Allah. Bahkan tanpa akal manusia tidak ubahnya seperti binatang yang hidup di muka bumi ini. Dengan bahasa yang singkat, akal menjadikan manusia sebagai makhluk yang berperadaban. Tetapi meskipun demikian, akal yang selalu diagungagungkan oleh golongan pemikir sebut saja golongan ra'yu atau mu'tazilah juga memiliki keterbatasan dalam fungsinya .(Nasution Harun, 1986: 71)

Akal itu adalah sebuah timbangan yang cermat, yang hasilnya adalah pasti dan dapat dipercaya (Ibnu Khaldun, 1999: 457). Khaldun menjelaskan mempergunakan akal itu menimbang soal-soal yang berhubungan dengan keesaan Allah swt, atau hidup di akhirat kelak, atau hakikat kenabian (nubuwah), atau hakikat sifat-sifat ketuhanan atau halhal lain di luar kesanggupan akal, 
adalah sama dengan mencoba mempergunakan timbangan tukang emas untuk menimbang gunung. Ini tidaklah berarti bahwa timbangan itu sendiri tidak boleh dipercaya. Soal yang sebenarnya ialah bahwa akal itu mempunyai batas-batas yang dengan keras membatasinya; oleh karena itu tidak bisa diharapkan bahwa akal itu dalam memahami Allah swt dan sifatsifatnya.

Akal akan mempertimbangkan hal-hal yang dilihat atau didengar lewat indera penglihatan atau pendengaran. Ini berarti bahwa akal dapat berfungsi setelah ada informasi yang bersifat empirik dari indera yang lain. Lalu bagaimana dengan fungsi akal untuk memikirkan hal-hal yang bersifat abstrak? hal-hal yang bersifat ghaib? Mempertimbangkan bahwa akal dapat berfungsi ketika ada informasi yang bersifat empirik dari panca indera yang lain, ini berarti akal akan berfungsi sebagaimana mestinya untuk hal-hal yang bersifat dapat diraba dan didengar. Adapun untuk hal-hal yang bersifat ghaib atau abstrak diperlukan petunjuk khusus, yakni wahyu (agama). Dengan begitu, meskipun di dalam al-Qur'an sangat ditekankan pada penggunaan akal dalam setiap persoalan, namun di sisi lain akal sangat membutuhkan wahyu (agama) atau lebih tepatnya religiusitas dalam menimbang hal-hal yang bersifat abstrak (ghaib).

Islam adalah agama yang sangat memperhatikan peran dan fungsi akal secara optimal, sehingga akal dijadikan sebagai standar seseorang diberikan beban taklif atau sebuah hukum. Jika seseorang kehilangan akal maka hukum-pun tidak berlaku baginya. Saat itu dia dianggap sebagai orang yang tidak terkena beban apapun. Di dalam Islam, dalam menggunakan akal mestilah mengikuti kaedah-kaedah yang ditentukan oleh wahyu supaya akal tidak terbabas, supaya akal tidak digiring oleh kepentingan, sehingga tidak menghalalkan yang haram dan mengharamkan yang halal, sehingga tidak menjadikan musuh sebagai kawan dan kawan pula sebagai musuh.

Meskipun demikian, akal bukanlah penentu segalanya. Ia tetap memiliki kemampuan dan kapasitas yang terbatas. Oleh karena itulah, Allah SWT menurunkan wahyu-Nya untuk membimbing manusia agar 
tidak tersesat. Di dalam

itu,ada

juga

keterbatasannya-lah akal manusia menjadi mulia. Sebaliknya, ketika ia melampaui batasnya dan menolak mengikuti bimbingan wahyu maka ia akan tersesat.

\section{METODE PENELITIAN}

Metode yang digunakan dalam penelitian ini adalah metode deskriptif kualitatif. Penelitian deskriptif merupakan penelitian yang bertujuan menggambarkan kedudukan akal dalam islam. Sedangkan sumbernya diambil dari beberapa buku-buku ilmiah yang diterbitkan dengan maksud dijadikan sumber referensi Adapun Tekhnik pengumpulan data dalam penelitian ini ialah Studi Kepustakaan, Wawancara dan Observasi.

\section{PEMBAHASAN}

Dalam Al-Qur'an tidak ditemukan kata aqala yang menunjuk potensi manusiawi itu. Yang ditemukan adalah kata kerjanya dalam bentuk ya'qilun dan ta'qilun(Quraish.2000:57). Masingmasing muncul dalam Alqur'an sebanyak 22 dan 24 kali. Di samping kata na'qilu dan qi'luha serta 'aqaluh $u$ yang masing-masing disebut sekali dalam al-Qur'an.

Terulangnya kata "akal" dan aneka bentuknya dalam jumlah yang sedemikian banyak mengisyaratkan pentingnya peranan akal. Bahkan kedudukan itu diperkuat oleh ketetapan al-Qur'an tentang pencabutan/pembatasan wewenang mengelola dan membelanjakan hartawalau milik seseorang bagi yang tidak memiliki akal/pengetahuan Qs. AnNisa (4): 5 .

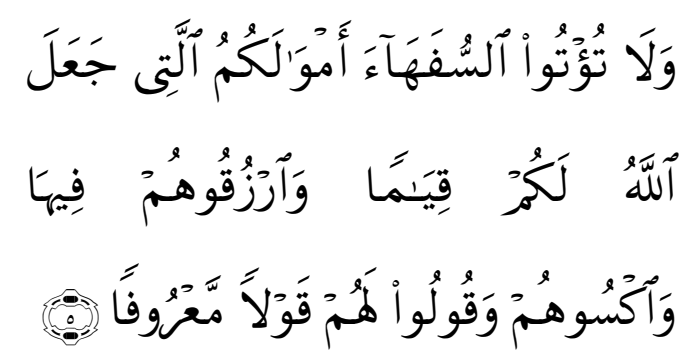

Terjemahnya:

"Dan janganlah kamu serahkan kepada orang-orang yang belum Sempurna akalnya, harta (mereka yang ada dalam kekuasaanmu) yang dijadikan Allah sebagai pokok kehidupan. berilah mereka belanja dan Pakaian (dari hasil harta itu) dan ucapkanlah kepada mereka kata-kata yang baik". 
Bahkan pengabaian akal berpotensi mengantar seseorang tersiksa di dalam neraka, seperti Qs. Al-Mulk (67):11
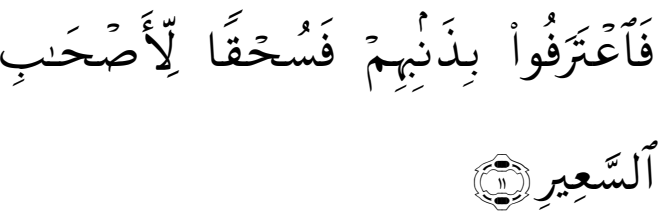

Terjemahnya:

"Mereka mengakui dosa mereka. Maka kebinasaanlah bagi penghuni-penghuni neraka yang menyala-nyala".

Melalui akal, lahir kemampuan menjangkau pemahaman sesuatu yang pada gilirannya mengantar pada dorongan berakhlak luhur. Ini dapat dinamai al-'aql al-wazi', yakni akal pendorong. Akal juga digunakan untuk memperhatikan dan menganalisis sesuatu guna mengetahui rahasia-rahasia yang terpendam untuk memperoleh kesimpulan ilmiah dan hikmah yang dapat ditarik dari analisis tersebut. Kerja akal di sini membuahkan ilmu pengetahuan sekaligus perolehan hikmah yang mengantar pemiliknya mengetahui dan mengamalkan apa yang diketahuinya. Ini dinamai al'aql al-mudrik, yakni akal penjangkau (pengetahuan).
Di samping kedua fungsi di atas, masih ada lagi yang melebihi keduanya, yaitu yang mencakup keduanya, tapi dalam bentuk yang sempurna dan matang sehingga tidak ada lagi kekurangan atau kekeruhan. Memang, bisa saja ada akal yang menghasilkan pengetahuan, tetapi (masih berpotensi mengandung) kekurangan hikmah. Demikian juga bisa jadi ada hikmah yang dilahirkan oleh mereka yang tidak berpengetahuan.

Al-Qur'an membicarakan ketiga fungsi di atas. Seperti Qs. Al-Baqarah (2): 164.


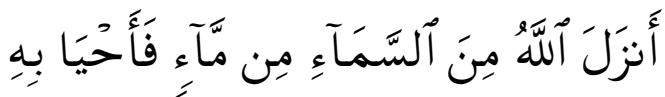

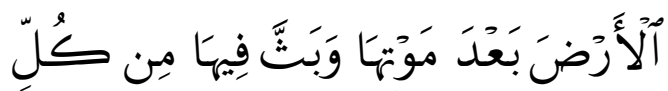

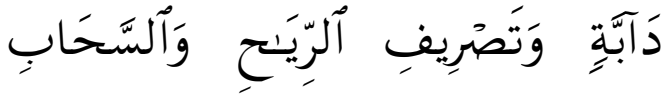






Terjemahnya:

"Sesungguhnya dalam penciptaan langit dan bumi, silih bergantinya malam dan siang, bahtera yang berlayar di laut membawa apa yang berguna bagi manusia, dan apa yang Allah turunkan dari langit berupa air, lalu dengan air itu dia hidupkan bumi sesudah mati (kering)-nya dan dia sebarkan di bumi itu segala jenis hewan, dan pengisaran angin dan awan yang dikendalikan antara langit dan bumi; sungguh (terdapat) tandatanda (keesaan dan kebesaran Allah) bagi kaum yang memikirkan”.

Ayat di atas mengajak manusia untuk menggunakan akalnya untuk memperhatikan fenomena alam dalam meraih pengetahuan.

Untuk meraih hal-hal di atas, maka akal harus difungsikan. Dalam konteks memfungsikannya, Al-Qur'an sekali menggunakan

kata yatafakkarun. kemudian

menggunakan ya'qilun. Danmengguna kankata yatadabbarun,selanjutnya yat adza kkarun, dan lain-lain. Semuanya mengarah pada upaya memfungsikan akal guna meraih pengetahuan atau pengetahuan dan hikmah, bahkan guna meraih rusyd yang menjadikan peraihnya dinamai Ulu alAlbab atau ar-Rasikhun fi alIlm (orang yang mantap dalam pengetahuannya).

Al-Qur'an tidak saja mengajurkan penggunaan akal, tetapi juga mengecam yang tidak menggunakannya untuk meraih ilmu dan hikmah. Ini antara lain terbaca dalam firman-Nya

Dalam Qs. Az-Zumar (39): 9



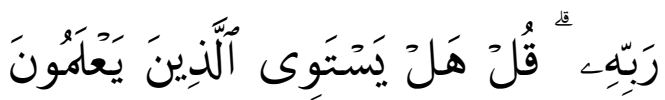

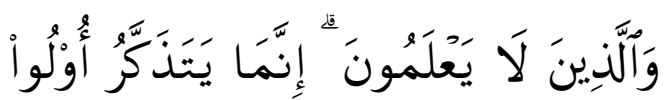

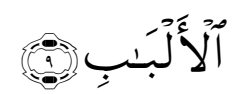

Terjemahnya:

"Apakah kamu Hai orang musyrik yang lebih beruntung) ataukah orang yang beribadat di waktu-waktu malam dengan sujud dan berdiri, sedang ia takut kepada (azab) akhirat dan mengharapkan rahmat Tuhannya? Katakanlah: "Adakah sama orang-orang yang mengetahui dengan orang-orang yang tidak mengetahui?" Sesungguhnya orang yang berakallah yang dapat menerima pelajaran".

Di samping itu, Al-Qur'an menggarisbawahi perlunya menghindari hal-hal yang dapat menghambat akal untuk berpikir lebih jernih dan beramal lebih baik. Kecaman Al-Qur'an terhadap mereka 
yang mengikuti tradisi leluhur tanpa dasar ilmu merupakan salah satu contoh dari penekanan kitab suci ini menyangkut pentingnya penggunaan akal. Memang, kaum muslim dituntut untuk percaya, tetapi kepercayaan yang harus didukung oleh ilmu dan dikukuhkan oleh hati yang suci, bukan sekadar percaya atas dasar pengamalan dan pengamalan leluhur.

Manusia sebagai pelaku dan obyek pendidikan dianugrahi oleh Allah swt., panca indera yang dapat digunakan untuk menjalani kehidupannya. Dengan demikian pendidikan harus berupaya mencerahkan manusia agar memiiki kecerdasan untuk dapat menggunakan panca inderanya, yaitu akal, dalam mencapai kehidupan yang baik, dan menjauhkan dirinya dari kehidupan yang tidak baik. Kajian terhadap akal ini sangat penting artinya oleh karena dampak yang dapat ditimbulkan dari akal tersebut bagi kehidupan amat besar.

Orang yang sempurna dan bersih akalnya, akan sampai kepada hikmah yang berada di balik proses mengingat (tazakkur) dan berfikir (tafakkur), yaitu mengetahui, memahami dan menghayati bahwa di balik fenomena alam dan segala sesuatu yang ada di dalamnya menunjukkan adanya Sang Pencipta, Allah swt., Dengan merenungkan penciptaan langit dan bumi, pergantian siang dan malam, akan membawa manusia akan kekuasaan Allah swt., yaitu adanya aturan yang dibuatnya serta karunia dan berbagai manfaat yang terdapat di dalamnya. Hal ini memperlihatkan kepada fungsi akal sebagai alat untuk mengingat dan berfikir.

$$
\text { Selanjutnya melalui }
$$
pemahaman yang dilakukan para mufassir terhadap ayat tersebut di atas akan dapat dijumpai peran dan fungsi akal tersebut secara lebih luas lagi. Menurut Ahmad Mustafa al-Maraghy (tp. th.:160) objek-objek yang difikirkan akal dalam ayat tersebut adalah al-khalq yang berarti batasan dan ketentuan yang menunjukkan adanya keteratutan dan ketelitian; alsamawat yaitu segala sesuatu yang ada di atas kita dan terlihat dengan mata kepala; al-ardl yaitu tempat dimana kehidupan berlangsung di atasnya; ikhtilaf al-lail wa al-nahar artinya 
pergantian siang dan malam secara beraturan; al-ayat artinya dalil-dalil yang menunjukkan adanya Allah dan kekuasaan-Nya. Lebih lanjut alMaraghy (tp. th:162) semua itu menjadi obyek atau sasaran di mana akal memikirkan dan mengingatnya. Tegasnya bahwa di dalam penciptaan langit dan bumi serta keindahan ketentuan dan keistimewaan penciptanya, serta adanya pergantian siang dan malam serta berjalannya waktu detik per detik sepanjang tahun, yang pengaruhnya tampak pada perubahan fisik dan kecerdasan yang disebabkan pengaruh panasnya matahari dan dinginnya malam, serta pengaruhnya pada binatang dan tumbuh-tumbuhan dan sebagainya adalah menunjukkan bukti keesaan Allah dan kesempurnaan ilmu dan kekuasaan-Nya.

Bukti empiris menunjukkan bahwa adanya perbedaan alam berikut cuacanya berpengaruh terhadap berbagai makhluk yang hidup di dalamnya. Di daerah pegunungan misalnya kita jumpai tumbuhtumbuhan seperti sayur mayur, anggur, apel, strawberry, delima, tomat, wortel dan sebagainya. Orang- orang yang mengonsumsi sayur-mayur tersebut memiliki sifat dan karakter yang khas. Sedangkan daerah pantai misalnya kita jumpai tumbuhtumbuhan yang berbeda pula, seperti pohon nyiur, tembakau, kakao dan sebagainya. Orang-orang yang hidup dan mengkonsumsi tumbuh-tumbuhan dan sebagainya yang ada di daerah pantai tersebut memiliki karakter yang berbeda dengan orang yang hidup di daerah pegunungan. Adanya fenomena empiris seperti ini akan membawa orang-orang yang berakal yang memikirkannya akan menyadari keagungan Allah Swt. Melalui upaya inilah manusia dapat mencapai kebahagiaan dan keselamatan hidup. Al-Maraghi (tp th :162) lebih lanjut mengatakan, bahwa keberuntungan dan kemenangan akan tercipta dengan mengingat keagungan Allah dan memikirkan terhadap segala makhlukNya. Kebahagiaan tersebut dapat dilihat dari munculnya berbagai temuan manusia dalam bidang ilmu pengetahuan dan teknologi yang pada hakikatnya merupakan generalisasi atau teorisasi terhadap gejala-gejala dan hukum-hukum yang terdapat di alam jagat raya. 
Penemuan dalam berbagai ilmu pengetahuan dan teknologi tersebut mengantarkan orang yang berakal untuk mensyukuri dan menyakini bahwa segala ciptaan Allah itu ternyata amat bermanfaat dan tidak ada yang sia-sia. Dalam hubungan ini orang berakal berkata rabbana maa khalaqta haza bathila subhanaka faqina 'azab al-naar (Ya Tuhan kami Engkau telah ciptakan semua ini dalam keadaan sia-sia, Maha Suci Engkau Ya Allah, dan karenanya jauhilah kami dari api neraka). Dalam tafsir Al-Maraghi dikatakan bahwa orang yang Al-Zakirun dan mutafakkirun (berakal) berkata Ya Tuhan kami Engkau tidak menciptakan apa yang tampak di alam ini baik yang ada di langit maupun di bumi, sebagai perbuatan yang sia-sia, Engkau tidak menciptakannya tanoa tujuan atau iseng-iseng. Maha Suci Engkau Tuhan kami yang jauh dari kesia-siaan dan kebathilan, melainkan seluruh ciptaan-Mu itu merupakan yang hak dan di dalamnya mencakup hukum-hukum dan ketentuan yang hebat dan mengandung kemaslahatan yang Agung.
Kajian terhadap peran dan fungsi akal sebagaimana dikemukakan pada ayat tersebut dalam perjalanan sejarahnya mengalami pasang surut. Pada masa Rasulullah Saw., hingga awal kekuasaan Bani Umayyah penggunaan akal demikian besar, melalui apa yang dalam ilmu fiqih di sebut ijtihad (Abd al Wahab. 1987:23). Hasil ijtihad ini muncul dalam bentuk ilmu-ilmu agama seperti tafsir, hadist, fiqih, ilmu tata bahasa, Qira'at dan sebagainya (Munawwar Khalil. 1975:145).

Penggunaan akal pikiran mengalami peningkatan yang luar biasa pada masa kekuasaan Bani Abbas (khususnya zaman alMakmun). Pada masa ini terjadi kontak umat Islam dengan pemikiran Yunani yang dijumpai pada beberapa wilayah yang sudah dikuasai Islam. Pada zaman inilah muncul para filosof muslim seperti al-Kindi, al-Farabi, Ibn Sina, al-Razi, Ibn Rusyd, Ibn Baja, Ibn Tufail dan sebagainya. Berbagai ilmu Agama Islam seperti ilmu fiqih, ilmu qalam, filsafat dan sebagainya yang muncul pada periode ini di pengaruhi oleh pandangan yang memberikan 
apresiasi dan penghargaan terhadap akal sebagaimana tersebut di atas.

Bersamaan dengan itu kajian terhadap istilah akal dijumpai di dalam Al-Qur'an semakin ditingkatkan. Dalam lisan al-Arab misalnya dijelaskan bahwa al- 'aql berarti al-hijr yang menahan dan menekan hawa nafsu. Selanjutnya Harun Nasution (1986:6) menerangkan pula bahwa al'aql mengandung arti kebijaksanaan (al-nuha) lawan dari lemah pikiran (al-humq). Selanjutnya disebutkan pula bahwa al-'aql juga mengandung arti kalbu (al-qalb). Lebih lanjut lagi dijelaskan bahwa kata aqala mengandung arti memahami. Demikian pula dalam kamus-kamus Arab dapat dijumpai kata aqala yang berarti memikat dan menahan.

Berbagai pengertian tentang akal sebagaimana tersebut di atas terjadi karena pengaruh dari pemikiran filsafat Yunani, yang banyak menggunakan akal pikiran. Seluruh pemikiran akal tersebut adalah menunjukkan adanya potensi yang dimiliki oleh akal itu sendiri, yaitu selain berfungsi sebagai alat untuk mengingat, memahami, mengerti, juga menahan, mengikat dan mengendalikan hawa nafsu. Melalui proses memahami secara mendalam terhadap segala ciptaan Allah sebagaimana dikemukakan pada ayat tersebut di atas, manusia selain akan menemukan berbagai temuan dalam bidang ilmu pengetahuan dan teknologi, juga akan membawa dirinya dekat dengan Allah. Dan melalui proses menahan, mengikat dan mengendalikan hawa nafsunya membawa manusia selalu berada di jalan yang benar, jauh dari kebinasaan.

Dalam pemahaman Profesor Izutzu, sebagaimana dikutip Harun Nasution (1986:5) bahwa kata 'aql di zaman jahiliyah dipakai dalam arti kecerdasan praktis (practical intellegence) yang dalam istilah psikologi modern disebut kecakapan memecahkan masalah (problem solving capacity). Orang berakal menurut Harun Nasution adalah yang mempunyai kecakapan untuk menyelesaikan masalah, setiap kali ia dihadapkan dengan problema dan selanjutnya dapat melepaskan diri dari bahaya yang ia hadapi. Kebijaksanaan praktis serupa ini dihargai oleh orang Arab zaman jahiliah. Orang yang berakal akan memiliki kesanggupan 
untuk mengelola dirinya dengan baik, agar ia selalu terpelihara dari mengikuti hawa nafsu, berbuat sesuatu yang dapat memecahkan dan memberikan kemudahan bagi orang lain, dan sekaligus orang yang tajam perasaan batinnya untuk merasakan sesuatu di balik masalah yang dipikirkannya. Dalam kaitan inilah, maka di dalam Al-Quran, sebagaimana dijelaskan pada Qs. AlHajj (22): 45

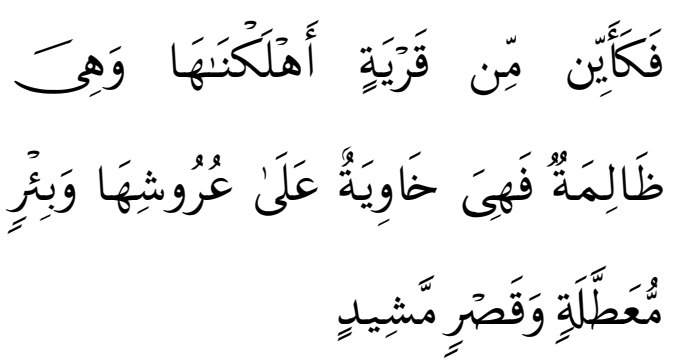

Terjemahnya;

"Berapalah banyaknya kota yang kami Telah membinasakannya, yang penduduknya dalam keadaan zalim, Maka (tembok-tembok) kota itu roboh menutupi atapatapnya dan (berapa banyak pula) sumur yang Telah ditinggalkan dan istana yang tinggi”,

Bahwa pengertian, pemahaman dan pemikiran dilakukan melalui kalbu yang berpusat di dada. Dengan kata lain ketika akal melakukan fungsinya sebagai alat untuk memahami apa yang tersirat di balik yang tersurat, dan dari padanya ia menemukan rahasia kekuasaan Tuhan, lalu ia tunduk dan patuh kepada Allah, maka pada saat itulah akal dinamai pula al-qalb. Akal dalam pengertian yang demikian itu dapat dijumpai pada pemakainnya di dalam Qs. al-Kahfi (18): 18



Terjemahnya:

"Dan kamu mengira mereka itu bangun, padahal mereka tidur; dan kami balik-balikkan mereka ke kanan dan ke kiri, sedang anjing mereka mengunjurkan kedua lengannya di muka pintu gua. dan jika kamu menyaksikan mereka tentulah kamu akan berpaling dari mereka dengan melarikan diri dan tentulah (hati) kamu akan dipenuhi oleh ketakutan terhadap mereka".

Menurut Daniel Goleman (2001:12) akal dalam pengertian yang demikian itulah yang kini disebut 
dengan istilah kecerdasan emosional, yaitu suatu kemampuan mengelola diri agar dapat diterima oleh lingkungan sosialnya. Hal ini didasarkan pada pertimbangan, bahwa keberhasilan seseorang di masyarakat, ternyata tidak semata-mata ditentukan oleh prestasi akademisnya di sekolah, melainkan juga oleh kemampuannya mengelola diri.

Pemahaman terhadap potensi berpikir yang dimiliki akal sebagaimana tersebut di atas memiliki hubungan yang amat erat dengan pendidikan. Hubungan tersebut antara lain terlihat dalam merumuskan tujuan pendidikan. Benyamin Bloom, cs., dalam bukunya Taxonomy of Educationl Objective (1956) membagi tujuan-tujuan pendidikan dalam 3 ranah (domain), yaitu ranah kognitif, afektif dan psikomotorik. Tiap-tiap ranah dapat dirinci lagi dalam tujuantujuan yang lebih spesifik yang hierarkis. Ranah kognitif dan afektif tersebut sangat erat kaitannya dengan fungsi kerja dari akal. Dalam ranah kognitif terkandung fungsi mengetahui, memahami, menerapkan, menganalisis, mensintesis dan mengevaluasi (Harun Nasution.
1994:50). Fungsi-fungsi ini erat kaitannya dengan fungsi akal pada aspek berpikir (tafakkur). Sedangkan dalam ranah afektif terkandung fungsi memperhatikan, merespon, menghargai, mengorganisasi nilai, dan menkarakterisasi. Fungsi-fungsi ini erat kaitannya dengan fungsi akal pada aspek mengingat (tazakkur), sebagaimana telah diuraikan di atas. Orang yang mampu mempergunakan fungsi berpikir yang terdapat pada ranah kognitif dan fungsi mengingat yang terdapat pada ranah afektif adalah termasuk ke dalam kategori Ulul al-bab. Orang yang demikian itulah yang akan berkembang kemampuan intelektualnya, menguasai ilmu pengetahuan dan teknologi, serta emosionalnya dan mampu mempergunakan semuanya itu untuk berbakti kepada Allah dalam arti yang seluas-luasnya. Manusia yang demikian itulah yang harus menjadi rumusan tujuan pendidikan, dan sekaligus diupayakan untuk mencapainya dengan sungguhsungguh.

Dengan demikian pendidikan harus mempertimbangkan manusia yang merupakan sasarannya sebagai 
makhluk yang memiliki akal dengan berbagai fungsinya yang amat variatif. Bertolak dari pertimbangan ini, maka materi atau mata pelajaran yang terdapat dalam kurikulum juga harus berisi mata pelajaran yang dapat merangsang pertumbuhan fungsi akal pikiran tersebut, seperti mata pelajaran matematika, sejarah, logika, tata bahasa dan sebagainya. Tujuan mata pelajaran sejarah misalnya tidak hanya untuk melatih ingatan terhadap berbagai peristiwa masa lalu lengkap dengan tahun, tempat, pelaku, sebabsebab, dan orang yang melakukannya, melainkan juga untuk membangun rasa kebanggaan, penghargaan dan sekaligus mengambil pelajaran yang berguna bagi dirinya dan masa depannya. Demikian pula tujuan mata pelajaran matematika tidak hanya mengajarkan anak didik memahami rumus-rumus matematika dan penerapannya dalam hitungan secara cepat, melainkan juga untuk membangun dan menciptakan sikap diri yang teliti, bekerja secara sistematik, obyektif dan hemat.

Berdasarkan uraian tersebut di atas, dapat diketahui bahwa dalam ajaran Islam akal mempunyai kedudukan tinggi dan banyak dipakai, bukan dalam perkembangan ilmu pengetahuan dan kebudayaan saja, tetapi juga dalam perkembangan ajaran-ajaran kepada keagamaan Islam sendiri. Pemakaian akal dalam Islam diperintahkan oleh Al-Qur'an. Karena Al-Qur'an itu sendiri baru dapat dipahami, dihayati dan dipraktekkan oleh orang-orang yang berakal. Selanjutnya sekuruh aturan ibadah dan lainnya dalam ajaran Islam baru diwajibkan apabila sasarannya (manusia) memiliki akal yang sudah berfungsi (baligh). Pemahaman terhadap berbagai fungsi akal yang terdapat dalam diri manusia harus dijadikan titik tolak dalam merumuskan tujuan dan mata pelajaran yang terdapat dalam kegiatan pendidikan. Pemahaman yang keliru terhadap akal sebagaimana pernah terjadi dalam sejarah dapat menyebabkan terjadinya kekeliruan pula dalam merumuskan tujuan dan materi pendidikan. Dengan demikian pemahaman yang tepat terhadap fungsi dan peran akal ini amat penting dilakukan, dan dijadikan pertimbangan dalam merumuskan masalah-masalah 
pendidikan, terutama masalah tujuan dan kurikulum pendidikan.

\section{PENUTUP}

Orang yang sempurna dan bersih akalnya, akan sampai kepada hikmah yang berada di balik proses mengingat (tazakkur) dan berfikir (tafakkur), yaitu mengetahui, memahami dan menghayati bahwa di balik fenomena alam dan segala sesuatu yang ada di dalamnya menunjukkan adanya Sang Pencipta, Allah swt

\section{DAFTAR PUSTAKA}

Al-Maraghi, Ahmad Mustafa. Tafsir Al-Maraghi. 1993. Semarang: PT. Karya Toha Putra.

Al-Wahidiy al-Naisabury, Abi alHasan Ali bin Ahmad. 1991. Asbab al-Nuzul. Beirut: Dar al-Fikr.

Departemen Agama. 1996. Al-Qur'an dan Terjemahannya. Semarang: Toha Putera.

Goleman, Daniel. 2001. Kecerdasan emosional. Bandung:Prima.

Katsir al Quraisy al-Dimasyqi, Abi alFida' Ismail. 1986. Tafsir Ibnu Katsir, Jilid 1. Makkah alMukarramah: al-Maktabah alTijariyah.
Khalaf, Abd al-Wahab. 1987. Ilmu Ushul Fiqh. Mesir: Dar al Ma'arif.

Khaldun, Ibnu. 1999. Muqaddimah Jilid III. t.tp.

Khalil, Munawwar. 1975. Salafiyah. Jakarta: Bulan Bintang.

Nasution, Harun. 1986. Akal dan Wahyu Dalam Islam. Jakarta: UI Pres.

------------.1994. Asas-asas Kurikulum. Jakarta: Bumi Aksara.

Shihab, M. Quraish. 2000. Logika Agama. Bandung: Lentera Hati.

Zabadiy, al-Fayruz. 1952. Al-Qamus Al-Muhith, cetakan II. Mesir: Al-Halabiy. 